\title{
Heterogeneity of sediments and settling particles in aerated ponds
}

\author{
Jawad Kassila* and Jérôme Hussenot
}

Centre de Recherche sur les Ecosystèmes Marins et Aquacoles, CNRS-Ifremer, L'Houmeau, France

*: Corresponding author : Kassila, 376 Avenue Mohamed V, 23000 Béni Mellal, Morocco. E-mail: kassilajawad@yahoo.com

\begin{abstract}
A study was conducted in seabass (Dicentrarchus labrax) and oyster (Crassostrea gigas) ponds to assess the levels of heterogeneity of sediments and settling particles. The intensity of sampling to estimate with high accuracy some characteristics will depend on the magnitude of the variation within the population under consideration. Several variables, such as total phosphate (Tot-P), total iron (Tot-Fe), total ammonium nitrogen (TAN), organic carbon (Org-C), total nitrogen (Tot-N) and $P$ fractions were analysed during the rearing period. The box-and-whisker plots were used as graphical/statistical tools to visualize the descriptive statistical characteristics of the data. In the fish pond, the sediments have high concentrations of Tot-P, Tot-Fe and TAN in comparison with the settling particles. The high $\mathrm{C} / \mathrm{N}$ ratios in the sediments indicate that the organic matter was more highly degraded in comparison with that of settling particles. The iron- and calcium-bound $\mathrm{P}$ (CaCO3 $\approx \mathrm{P}$ ) represented $23 \%$ and $47 \%$ of Tot-P respectively in the fish-pond sediments, whereas the Tot-P was essentially under organic form in the settling particles. In the oyster pond, the trapping rate of solids reached $417 \mathrm{~g} \mathrm{~m}-2$ day- 1 under the trestles. The material consisting mostly of oyster rejection products was less degraded. The similarity in the $\mathrm{C} / \mathrm{N}$ ratios indicated that the organic matter collected under the oyster trestles was not different from that collected out of trestles. We used multivariate analysis to determine the number of samples needed to be taken to represent the $\mathrm{C}, \mathrm{N}$ and $\mathrm{P}$ average amounts. The principal component analysis (PCA) indicates that the $\mathrm{CaCO} 3 \approx \mathrm{P}$ and Tot-Fe are the key factors to describe the spatial heterogeneity of the fish-pond sediments. However, the analysis gives no indication of the heterogeneity of settling particles. A partition of the studied stations into different classes was performed by the hierarchical ascending classification (HAC). To assess the variability of the sediments and settling particles during the rearing period, one station could be selected from each group for the next sampling. We used a dilution analysis method to evaluate the magnitude of sedimentation and resuspension in the fish pond. The calculated proportion of resuspension relative to the total flux ranged from $71 \%$ to $80 \%$ in the fish pond. The ranges of Org-C and Tot- $\mathrm{N}$ in the resuspension rate were $19-41$ and $2.6-6.7 \mathrm{~g} \mathrm{~m}-2$ day-1 respectively.
\end{abstract}

Keywords: sediment, particles, artiфcial aeration, sedimentation, resuspension, sampling strategy 


\section{Introduction}

Water quality management has been considered one of the most important aspects of pond aquaculture for many years, but less attention has been given to the management of pond bottom soil quality. There is increasing evidence that the condition of pond bottoms and the exchange of substances between soil and water strongly influence water quality (Boyd, 1995). Furthermore, little effort has been made to evaluate sampling methods that provide representative information of aquaculture pond bottoms. To obtain a representative sample of the pond bottom, Boyd (1995) suggested taking sediment samples along several transects from the shallow to the deep end of the pond. The method proposed by Brune \& Eversole (1993) divided each pond into six equal areas, and took the sediment sample from the center of each section. A system of nine quadrats is often employed for sampling soils in agronomic studies, and it is suitable for application in aquaculture ponds. The sampling point in each quadrate should be randomly selected. The above studies indicate different methods for sediment sampling. However, no details were provided regarding the efficiency of these methods.

Intensive fish ponds are examples of hypereutrophic systems with high inputs of nutrients, particularly N, as formulated feed. Much of this feed is not retained by the culture species but enters the pond system as particulate and dissolved nutrients (Martin et al. 1998; Lefebvre et al., 2001). Aquaculture ponds require artificial aeration when stock biomass exceeds the natural re-aeration rate delivered by wind, photosynthesis, and water exchange (Boyd, 1998). Aerators may deliver oxygen, while also stripping carbon dioxide and nitrogen. The same machines can also act to resuspend bottom particles and drive some substances across the water-sediment interface. Resuspension of particles from pond bottom into the water column may be an important nutrient transfer mechanism in aquaculture ponds. Resuspension depends upon the sheer stress created by water currents on the pond bottom, the less consolidated soils being more sensitive (Lee, 1970). However, the magnitude of sediment resuspension cannot be determined directly because sediment traps deployed in muddy ponds collect particles settling from the water column as well as those resuspended from the pond bottom. Avnimelech et al. (1999) developed a dilution analysis method to differentiate the magnitude of the two particle source fluxes based upon the concentration of sediment-derived elements ( $\mathrm{Si}, \mathrm{Al}$ and $\mathrm{Fe}$ ) and water-derived elements ( $\mathrm{C}, \mathrm{N})$ in material collected by sediment traps. Jimenez-Montealegre et al. (2002) have reported that the use of $\mathrm{Fe}$ and $\mathrm{Al}$ as tracers for estimating resuspension gave similar results and the use of one tracer is sufficient for this study.

The experimental fish ponds of CREAA (French Atlantic coast) were supplied with seawater and aerated continuously with two propeller-aerators, positioned 'in-line' within the perimeter of the pond. The aerators were positioned to direct water parallel to the pond bank. This aeration results in erosion of pond bottoms and inside slopes of embankments, and accumulation of sediment in areas where water currents are weaker. The TSS concentration reached $450 \mathrm{mg} / \mathrm{l}$ in areas near the aerators $(<5 \mathrm{~m})$. The water renewal rate varied from 20 to $60 \%$ per day depending on fish biomass and temperature.

Traditional methods of wastewater (sewage) treatment are ineffective and expensive for application in treating fish pond effluent (Hopkins et al., 1995). A potentially viable alternative is biological treatment of the effluent using oysters and macroalgae to remove suspended particulates and nutrients (Shpigel et al., 1993). Previous studies have shown that filtration by oysters can significantly reduce the concentration of bacteria, phytoplankton, total nitrogenous and total phosphorus in fish pond effluent (Jones \& Preston, 1999).

The nutrients generated by the fish production in the CREAA ponds are not always efficiently used by micro-algae. Indeed, only a proportion (10-20\%) of P-wastes is converted into 
mollusc flesh (Lefebvre, 2000). The rest is adsorbed on sediments and suspended particles or discharged as pseudo-faeces. Consequently, the $\mathrm{P}_{-} \mathrm{PO}_{4}$ must be often added to ponds at frequent intervals to maintain optimal $\mathrm{N}: \mathrm{P}$ ratio (atom-atom) near the Redfield ratio $(\mathrm{N}: \mathrm{P}=$ 16:1) and to support therefore high levels of algae production for shellfish feeding. As the $\mathrm{P}$ fractions in sediment have different chemical and biological properties, for a better knowledge of the $\mathrm{P}$ cycle in aquaculture systems, it is essential to measure them separately by a fractionation method.

The aim of this study was to assess levels of heterogeneity of sediments and settling particles in seabass and oyster ponds in order to improve the choice of representative sampling locations for these ponds. This sampling strategy should allow estimation of the chemical parameters during the rearing period. In this study, two successive steps were carried out as follows:

- Description of the heterogeneity of the sediments and settling particles through a visualisation technique using chemical analysis and P-fractionation data.

- Optimisation of the sampling strategy using two multivariate analyses.

An additional study was conducted in the fish pond to evaluate the magnitude of sedimentation and resuspension using the dilution analysis method (Avnimelech et al., 1999) and to identify the principal factors that contribute to resuspension or sedimentation.

\section{Methods}

The ponds of CREAA (Regional centre for aquaculture experiments) located on the French Atlantic coast, have been designed to evaluate a novel land-based marine integrated aquaculture system and propose it for commercial application in temperate waters (European Innovation Project: GENESIS ${ }^{1}$ ). The goal of the system is to reduce environmental impact and improve nutrient utilization through diversification of production (Shpigel et al., 1993; Hussenot \& Shpigel, 2003). It consists of a semi-intensive fish pond (seabass, Dicentrarchus labrax) associated with a sedimentation pond, two phytoplankton ponds, and two bivalve ponds. The effluent from the seabass pond is treated by micro-algae bio-filters after settling (Hussenot, 2003). The grown algae are transferred to feed shellfish that convert the low-value algal by-product into a high-value commodity.

The earthen fish pond of $560 \mathrm{~m}^{2}$ and $1.2 \mathrm{~m}$ depth was stocked with $744 \mathrm{~kg}$ of seabass (Dicentrarchus labrax) at 7.4 fish $\mathrm{m}^{-2}$. The pond was aerated with 2 propeller-aerators positioned 'in-line' (series) within the perimeter of the pond (Fig. 1a). Fish were fed with dry pellets (50\% crude protein, $1.42 \%$ phosphorus), at $2 \%$ body weight per day. The daily ration was divided into two equal portions applied manually at 10:00 and 17:00 over the pond surface. The feeding conversion ratio (FCR) was 1.94 during the rearing period.

The bivalve pond of $92 \mathrm{~m}^{2}$ and $1.5 \mathrm{~m}$ depth was stocked with about $30 * 10^{3}$ of the pacific oyster (Crassostrea gigas) (mean weight $\sim 4.9$ g). The oysters were placed in bags supported on the trestles. The water circulation was created by six airlifts as indicated in Fig. 1b. The water renewal rate varied from 150 to $200 \%$ per day with temperature and oyster biomass to maintain limit values for water quality parameters (TAN, $\mathrm{O}_{2}$ and $\mathrm{pH}$ ).

\footnotetext{
${ }^{1}$ Generic Sustainable integrated aquaculture System. http://genesis.ocean.org.il/main.htm.
} 
Figure 1 Sampling stations in the fish (a) and oyster (b) ponds ( : Sediment traps ${ }^{+}$: Sediment sampling, $\mathrm{A}_{1}$ and $\mathrm{A}_{2}$ : aerators, $\mathrm{AL}_{1}, . ., \mathrm{AL}_{6}$ : airlifts, OT: out of the trestles and UT: under the trestles ). The triple arrows in the oyster pond indicate the water circulation induced by the airlifts.

$\hat{\mathrm{N}}$

a

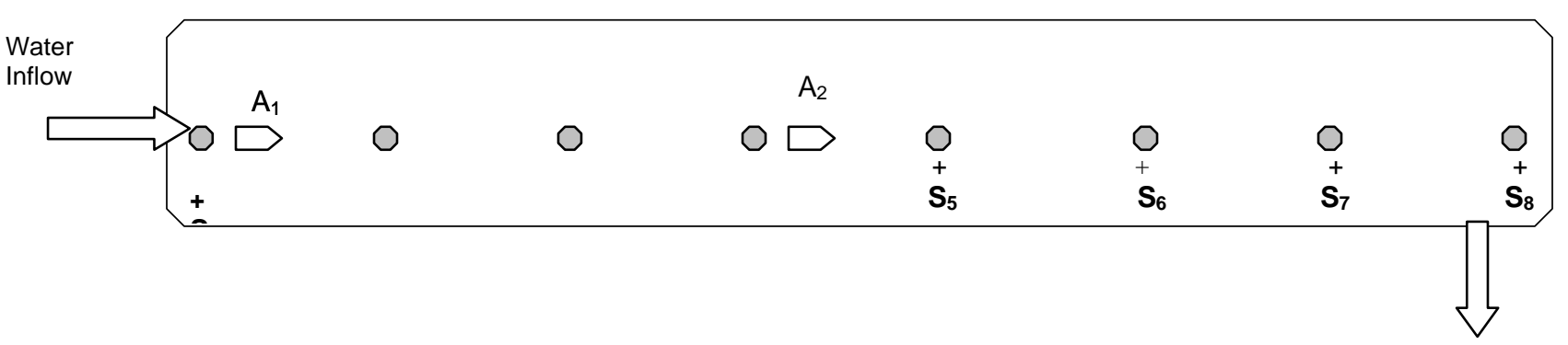

b

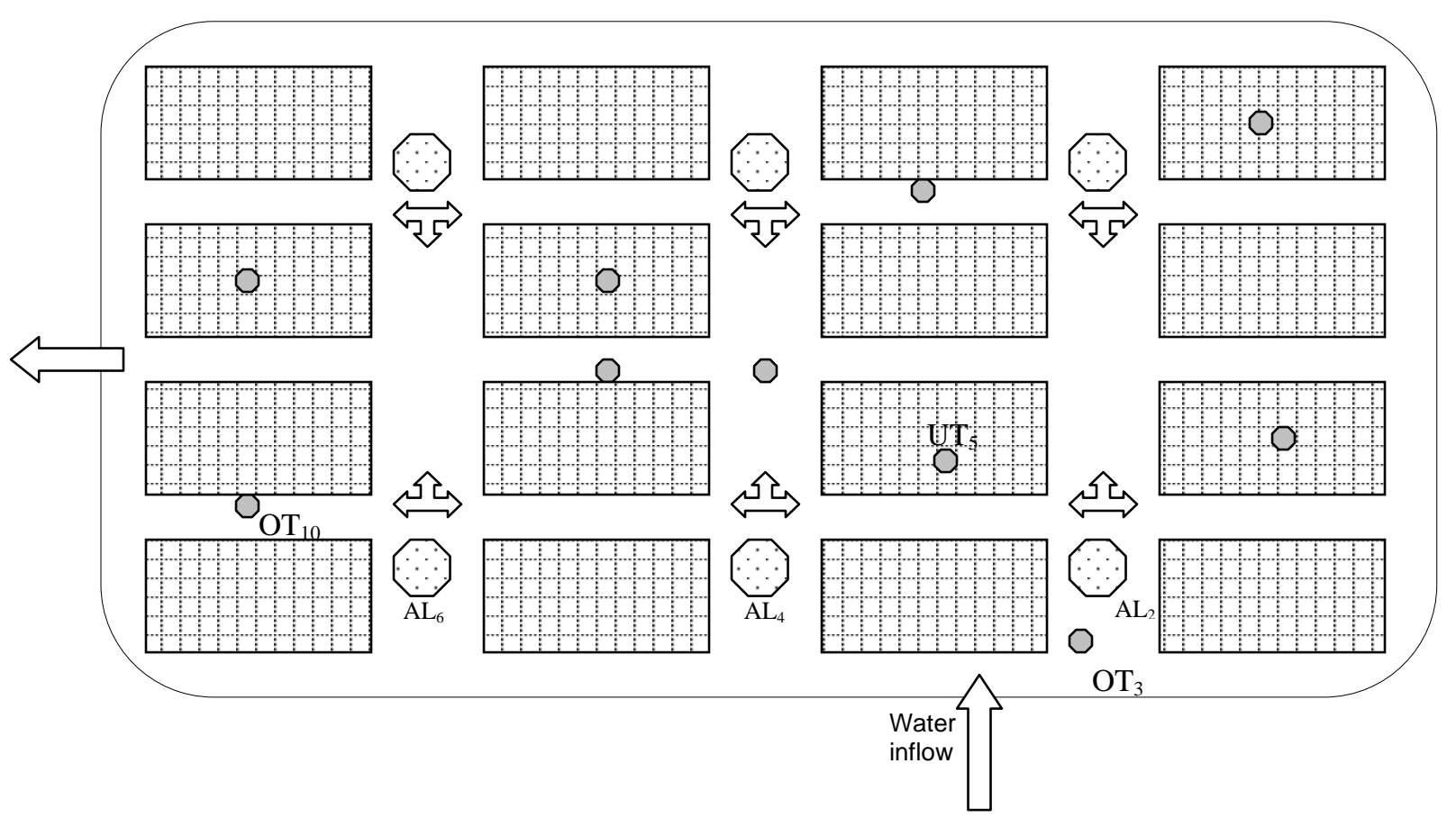


Fish pond sediment was taken from eight stations at $15 \mathrm{~m}$ apart (Fig. 1a). Ritvo et al. (1998) reported that samples need to be taken 15 and $20 \mathrm{~m}$ apart to estimate the average amount of nutrients in the pond sediments. A core sampler of $7.5 \mathrm{~cm}$-diameter was used to sample the 0 $0.5 \mathrm{~cm}$ layer.

Plate plastic boxes (21.7 cm length, $12.9 \mathrm{~cm}$ wide, $6.7 \mathrm{~cm}$ height) used as sediment traps were deployed on the pond bottom. Plate traps are the most accurate tools to estimate the total flux of sedimentation in slowly flowing rivers and shallow aquatic systems where resuspension is high (Kozerski \& Leuschner, 1999; Banas \& Masson, 2003). In shallow systems (1.2 m deep), traditional traps neglect a large part of the water column and underestimate the downward settling flux of particulate matter by 35 to 79 \% (Rosa et al., 1994; Banas et al.,2002). The mouth of the boxes was protected with a honeycomb style baffle, trapped all sedimenting material (net sedimentation + local resuspension) (Sornin et al., 1990). The purpose of using baffles at the top of traps is to decrease the size of turbulent eddies and rate of mixing within a trap (Gardner, 1980). The cells of the baffle have a height/diameter ratio $=5$ to prevent the resuspension of the material trapped. In the fish pond, the sediment traps were placed near to the sediment stations during 3 days (Fig. 1a). Ten sediment traps were placed on the oyster pond bottom during 7 days: $\mathrm{UT}_{1}, \mathrm{UT}_{2}, \mathrm{UT}_{5}, \mathrm{UT}_{7} \& \mathrm{UT}_{9}$ were positioned under the oyster trestles, and $\mathrm{OT}_{3}, \mathrm{OT}_{4}, \mathrm{OT}_{6}, \mathrm{OT}_{8} \& \mathrm{OT}_{10}$ were positioned out of the trestles (Fig. 1b). The trapped material was dried and weighted to measure total mass flux.

The sediment samples collected were first subject to redox potential $\left(\mathrm{E}_{\mathrm{h}}\right)$, water content and $\mathrm{pH}$ determinations. Several variables such as tot-P, tot-Fe, TAN, org-C, tot-N and Pfractionation were analyzed in the sediments and trapped materials.

For the water content determination, samples from 0-0.5 cm layer were weighted and dried at $65^{\circ} \mathrm{C}$ until constant weight. The tot-P and tot-Fe were determined after digestion with $\mathrm{H}_{2} \mathrm{O}_{2} / \mathrm{H}_{2} \mathrm{SO}_{4}$ of $0.20 \mathrm{~g}$ d.w. sediments during $2 \mathrm{~h}$ at $130^{\circ} \mathrm{C}$. The $\mathrm{P}$ and Fe were measured colorimetrically using respectively the blue-molybdate method (Murphy \& Riley, 1962) and the o-phenantroline method (Golterman et al., 1978) after centrifugation and neutralisation. TAN $\left(\mathrm{N}-\mathrm{NH}_{4}{ }^{+}+\mathrm{N}-\mathrm{NH}_{3}\right)$ was measured by colorimetric method (Koroleff \& Grasshoff, 1983) after extraction with $\mathrm{KCl}(1 \mathrm{M})$. Org-C and tot-N were measured using a Carlo Erba CHN analyzer (Model NA1500).

The EDTA procedure (Golterman, 1996) was applied to extract different P-fractions from the sediments and settling particles. The other procedures underestimate the organic $\mathrm{P}$ present in the sediments, whereas the calcium-bound P is overestimated (Mesnage \& Picot, 1993; Kassila et al., 2000). The fractional composition was determined on $0.5 \mathrm{~g}$ d.w., by means of sequential extraction with Ca-EDTA/dithionite to extract $\mathrm{Fe}(\mathrm{OOH}) \approx \mathrm{P}$ and with Na-EDTA to extract $\mathrm{CaCO}_{3} \approx \mathrm{P}$ (Golterman 1996), followed by an extraction of Acid Soluble Organic Phosphate (ASOP) with $0.5 \mathrm{M} \mathrm{HCl}$ (De Groot, 1990). Thereafter, an extraction with $2.0 \mathrm{M}$ $\mathrm{NaOH}\left(90^{\circ} \mathrm{C}\right)$ was carried out. After centrifugation a digestion with $\mathrm{K}_{2} \mathrm{~S}_{2} \mathrm{O}_{8}$ and $\mathrm{H}_{2} \mathrm{SO}_{4}$ was performed on the supernatant to determine $\mathrm{NaOH}_{\text {ext }}-\mathrm{P}$, which was measured as o-P after neutralisation (De Groot, 1990). The Residual Organic Phosphate (ROP) was obtained after the digestion of the final pellet with $\mathrm{K}_{2} \mathrm{~S}_{2} \mathrm{O}_{8} / \mathrm{H}_{2} \mathrm{SO}_{4}$. Phosphate concentrations of the supernatants were determined colorimetrically using the blue-molybdate method (Murphy \& Riley, 1962). $\mathrm{Fe}(\mathrm{OOH})$ was determined after centrifugation and neutralisation with ophenantroline using ascorbic acid as reductant (Golterman et al., 1978). 
Partition of Sedimentation and Resuspension Fluxes in the fish pond

Studies to partition the sources of trapped particulate matter were based on traps placed in the fishpond. Resuspension can be differentiated from sedimentation because the elemental composition of resuspended particles is distinct from particles originating in the water column. Avnimelech et al. (1999) proposed a dilution analysis method to evaluate the magnitude of sedimentation and resuspension based on the assumption that particles originating in the water column are mainly organic, while particles resuspended from the pond bottom are mainly mineral and contain elements (Fe, $\mathrm{Al}, \mathrm{Si}$ ) abundant in the soil.

The dry weight concentration of an element in the trapped material $\mathrm{C}_{\text {tot }}$ is the weighted average of the concentration in sedimentation $\mathrm{Cs}$ and resuspension $\mathrm{Cr}$ fluxes:

$$
\mathrm{C}_{\text {tot }}=\left(\mathrm{W}_{\mathrm{s}} \mathrm{C}_{\mathrm{s}}+\mathrm{W}_{\mathrm{r}} \mathrm{C}_{\mathrm{r}}\right) / \mathrm{W}_{\text {tot }} \text {, }
$$

Where Ws and $\mathrm{Wr}$ are the dry weights of material collected from sedimentation and resuspension respectively and $\mathrm{Wt}$ : the total weight collected in the trap. That is,

$$
\mathrm{W}_{\mathrm{r}}+\mathrm{W}_{\mathrm{s}}=\mathrm{W}_{\text {tot }} \text {. }
$$

Combining these two equations and re-arranging:

$$
\mathrm{W}_{\mathrm{r}} / \mathrm{W}_{\text {tot }}=\left(\mathrm{C}_{\text {tot }}-\mathrm{C}_{\mathrm{s}}\right) /\left(\mathrm{C}_{\mathrm{r}}-\mathrm{C}_{\mathrm{s}}\right)
$$

$\mathrm{C}_{\mathrm{r}}$, the concentration of the relevant component (Fe, $\mathrm{Al}$ or $\mathrm{Si}$ ) of the resuspension flux, was assumed to be identical to the composition of the upper layer of the pond bottom. Avnimelech et al. (1999) have reported that $\mathrm{C}_{\mathrm{s}}$, the concentration of soil-derived elements in the sedimentation flux was negligible and was assumed to be zero. This assumption can be applied only for ponds that are supplied with water having negligible suspended clay and that do not have large diatom populations. Only Fe was used in this study as tracer and the $\mathrm{C}_{\mathrm{s}}$ was estimated to be $1.57 \mathrm{mg} \mathrm{Fe} \mathrm{g}^{-1} \mathrm{~d}$.w. The determination of Fe with o-phenantroline is more simpler compared to $\mathrm{Al}$ and $\mathrm{Si}$ analyses

\section{Statistical analysis}

The results of the chemical composition and P-fractionation are presented in Box-andWhisker plots, which are a powerful statistic displaying the median, range and the shape of the data distribution. This method allows a great deal of flexibility because we can compare not only the distribution of a single continuous variable but also the distribution of groups as defined by nominal values. The cross in the box is the median of the data, the top and the bottom of the box are the quartiles, the end of the whiskers are the $10^{\text {th }}$ and $90^{\text {th }}$ percentiles, and the round marks indicate the min and the max of data. As this is a visual comparison, we used the nonparametric-paired Wilcoxon test to confirm the differences between stations.

A principal component analysis (PCA) and a hierarchical ascending classification were performed using XL STAT Pro software program. The matrix contained 11 variables (Tot-P, Tot-N, Tot-Fe, TAN, Org-C, $\mathrm{Fe}(\mathrm{OOH}), \mathrm{Fe}(\mathrm{OOH}) \approx \mathrm{P}, \mathrm{CaCO}_{3} \approx \mathrm{P}, \mathrm{ASOP}, \mathrm{NaOH}_{\text {ext }} \mathrm{P}$ and ROP) and 26 individuals ( 8 sampling sites for sediments and 18 for settling particles). The chemical and P-fractionation data were set as active variables.

\section{Results}

The fish biomass reached $1160 \mathrm{Kg} /$ ha in 118 days with a feed conversion ratio (FCR) of 1.94 during the rearing period. The feed input at the beginning of the experiment was $9 \mathrm{~g} / \mathrm{m}^{2}$ per day, and reached $18 \mathrm{~g} / \mathrm{m}^{2}$ per day on day 118 . 
The trapping rates of solids ranged from 2720 to $5400 \mathrm{~g} / \mathrm{m}^{2} / \mathrm{d}$ in the fish pond with a mean of $3975 \mathrm{~g} / \mathrm{m}^{2} / \mathrm{d}$ (Fig. 2a). The high rates were recorded in $S_{3}$ and $S_{7}$ located at 32 and $40 \mathrm{~m}$ respectively from the aerators.

Figure 2 Total matter collected by sediments traps in the fish (a) and oyster (b) ponds. Mean \pm SD
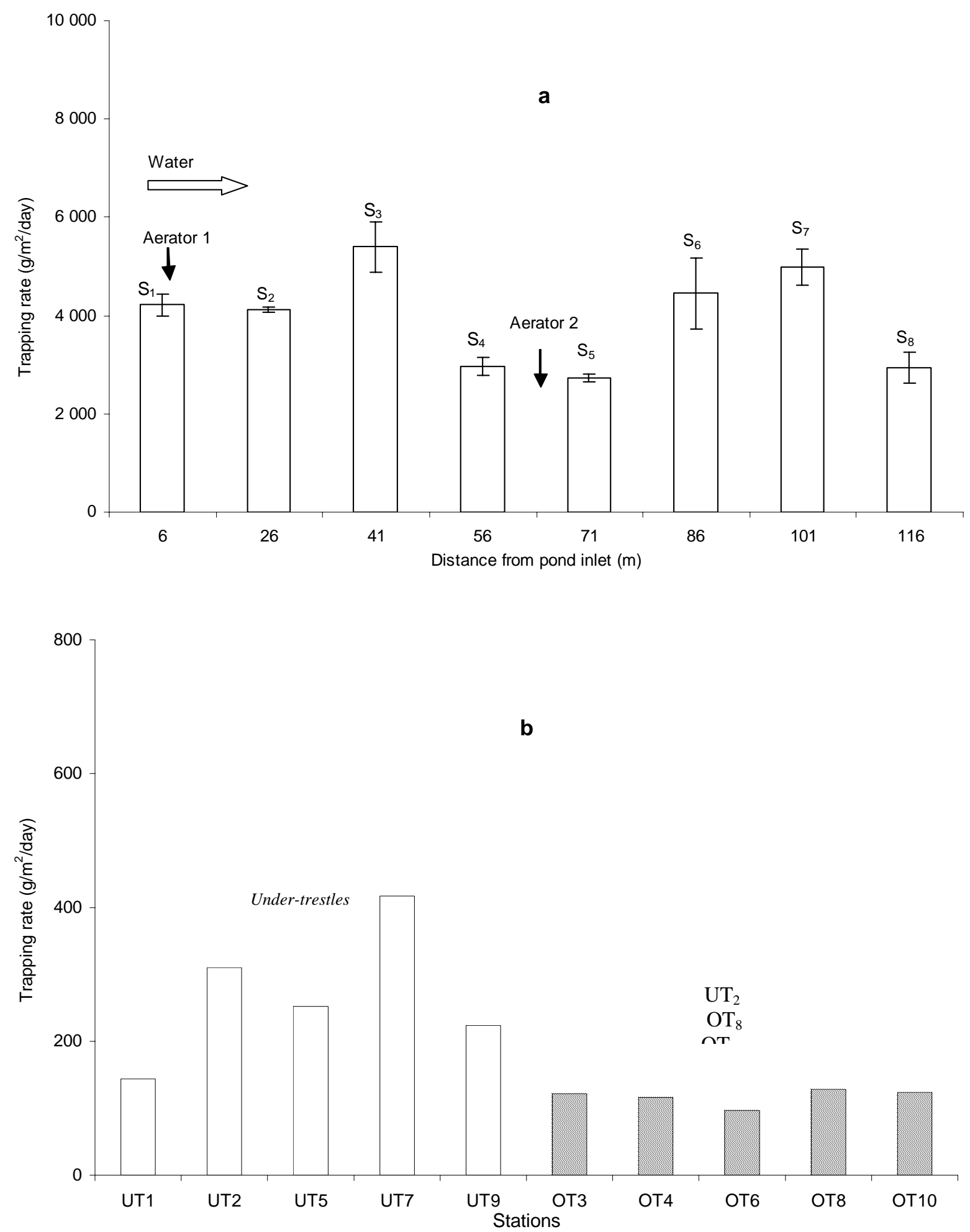
In the oyster pond, the trapping rates reached $417 \mathrm{~g} / \mathrm{m}^{2} / \mathrm{d}$ under the trestles, whereas they did not exceed $130 \mathrm{~g} / \mathrm{m}^{2} / \mathrm{d}$ out of the trestles (Fig. 2b). No significant difference was recorded among the OT stations. Only $144 \mathrm{~g} / \mathrm{m}^{2} / \mathrm{d}$ as rate was recorded in $\mathrm{UT}_{1}$ positioned under one bag line. The $\mathrm{UT}_{2}, \mathrm{UT}_{5}, \mathrm{UT}_{7}$ and $\mathrm{UT}_{9}$ sediments traps were placed under three bag lines of oyster.

\section{Partition of Sedimentation and Resuspension Fluxes}

The dilution analysis method using Fe as a tracer was applied to calculate the sedimentation and resuspension proportions in the fish pond. The calculated proportion of resuspension relative to the total flux ranged from 71 to $80 \%$ in the fish pond (Fig. 3a). The high resuspension rates were obtained in $S_{3}, S_{6}$ and $S_{7}$ with a maximum of $4140 \mathrm{~g} / \mathrm{m}^{2} / \mathrm{d}$ (Fig. $3 \mathrm{~b}$ ). Depending on the stations, resuspension rates were two to four times higher than those of sedimentation. An important decrease in resuspension occurred in $S_{5}$ located at $10 \mathrm{~m}$ from aerator 2 . The spread of the second peak indicates that the aerator 2 was more powerful than the aerator 1 in inducing resuspension. The resuspended particles then accumulated in areas where water currents are weaker, as in $\mathrm{S}_{6}$ and $\mathrm{S}_{7}$. 
Figure 3 Source of material collected in the fish pond (a) and sedimentation and resuspension rates estimated from total solids (b). Mean \pm SD.
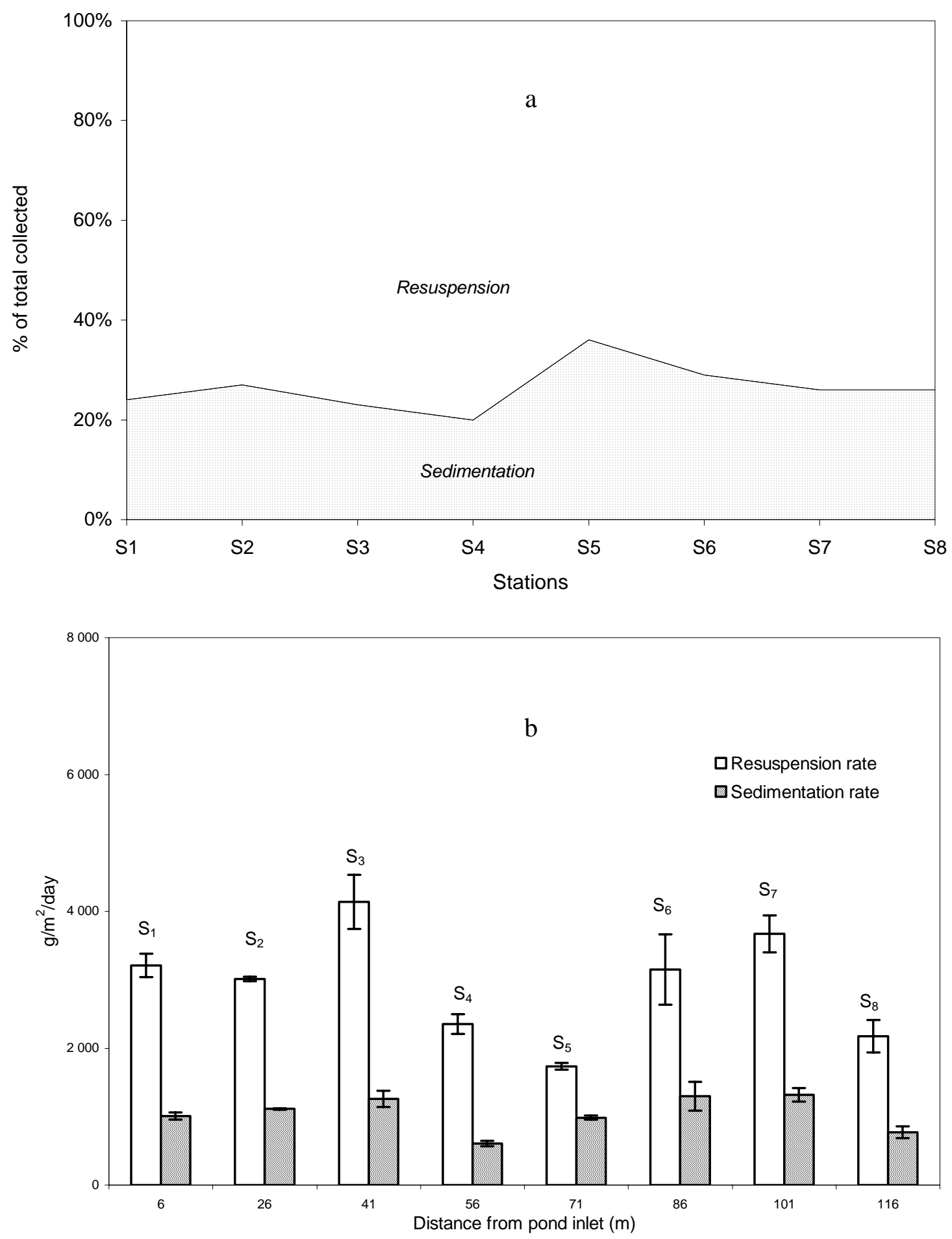
The sedimentation, which accounted for $20-29 \%$ of the material collected in the traps, did not exceed $1320 \mathrm{~g} / \mathrm{m}^{2} / \mathrm{d}$ as a flux. The estimated org-C and tot $\mathrm{N}$ in the resuspension rate were 1941 and $2.6-6.7 \mathrm{~g} / \mathrm{m}^{2} / \mathrm{d}$ respectively (Fig. 4) and evolved in parallel along the pond. The maximum rates were recorded in $S_{3}$ located at $32 \mathrm{~m}$ from the aerator 1 . These parameters remained almost constant in the sedimentation rates except in $\mathrm{S}_{4}$ and $\mathrm{S}_{8}$ where an important decrease occurred.

Figure 4 Resuspension and sediments rates of org-C and tot-N. Mean \pm SD.
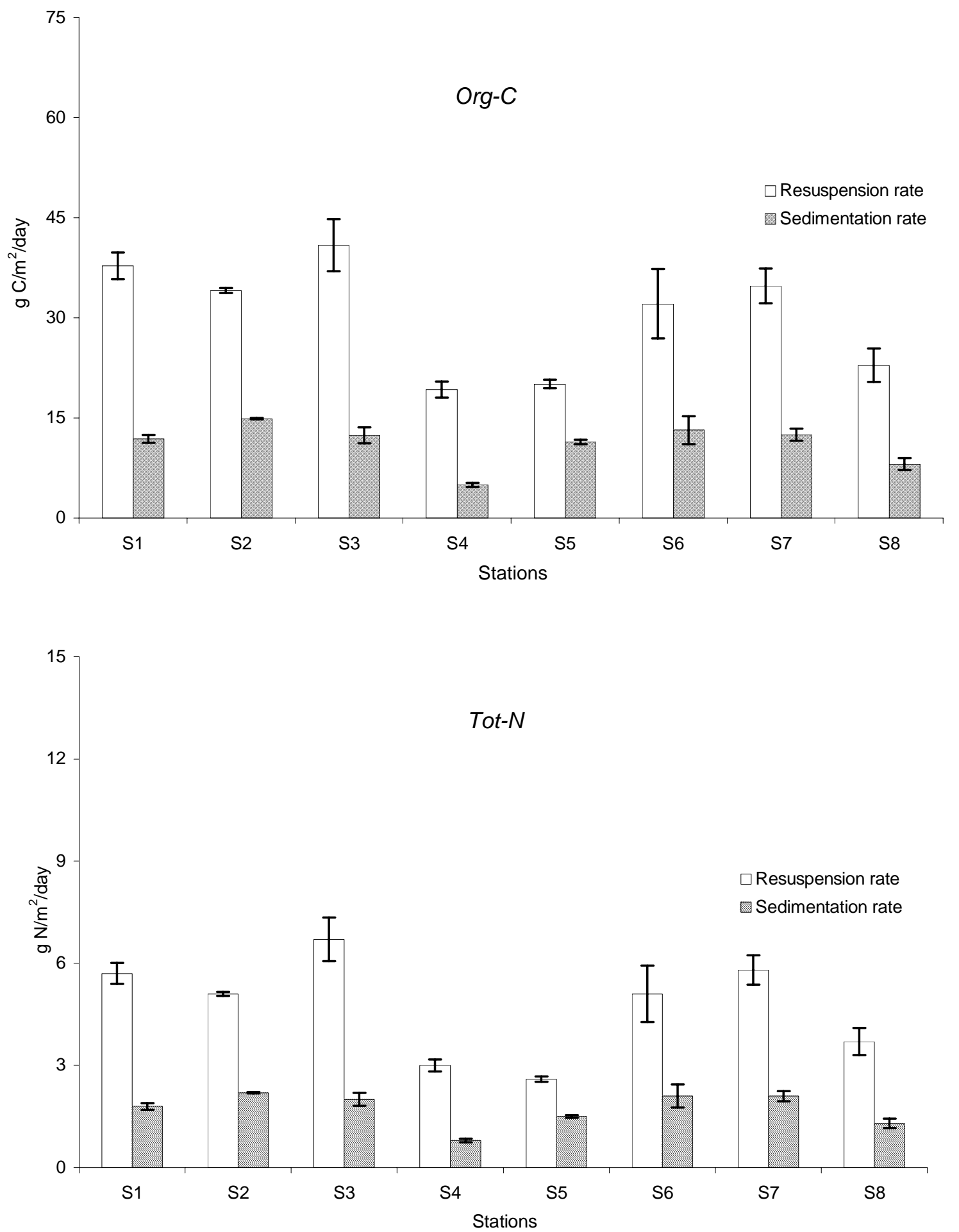
The results summarised in Fig. 5 showed that the redox potential $\left(\mathrm{E}_{\mathrm{h}}\right)$ ranged between -4 and $+220 \mathrm{mV}$ in the superficial sediments. The sediments collected from $\mathrm{S}_{3}$ and $\mathrm{S}_{6}$ were relatively more oxidized $\left(E_{h}>180 \mathrm{mV}\right)$ than the other sites. The lowest $E_{h}$ was recorded in $S_{7}$ located at $40 \mathrm{~m}$ from the aerator 2 . The $\mathrm{pH}$ of the sediment varied slightly between 6.9 and 7.2 in the different stations. For the water content an increase of $46 \%$ occurred from $S_{1}$ to $S_{4}$.

Figure $5 \mathrm{E}_{\mathrm{h}}, \mathrm{pH}$ and Water content data of the sediments at different stations

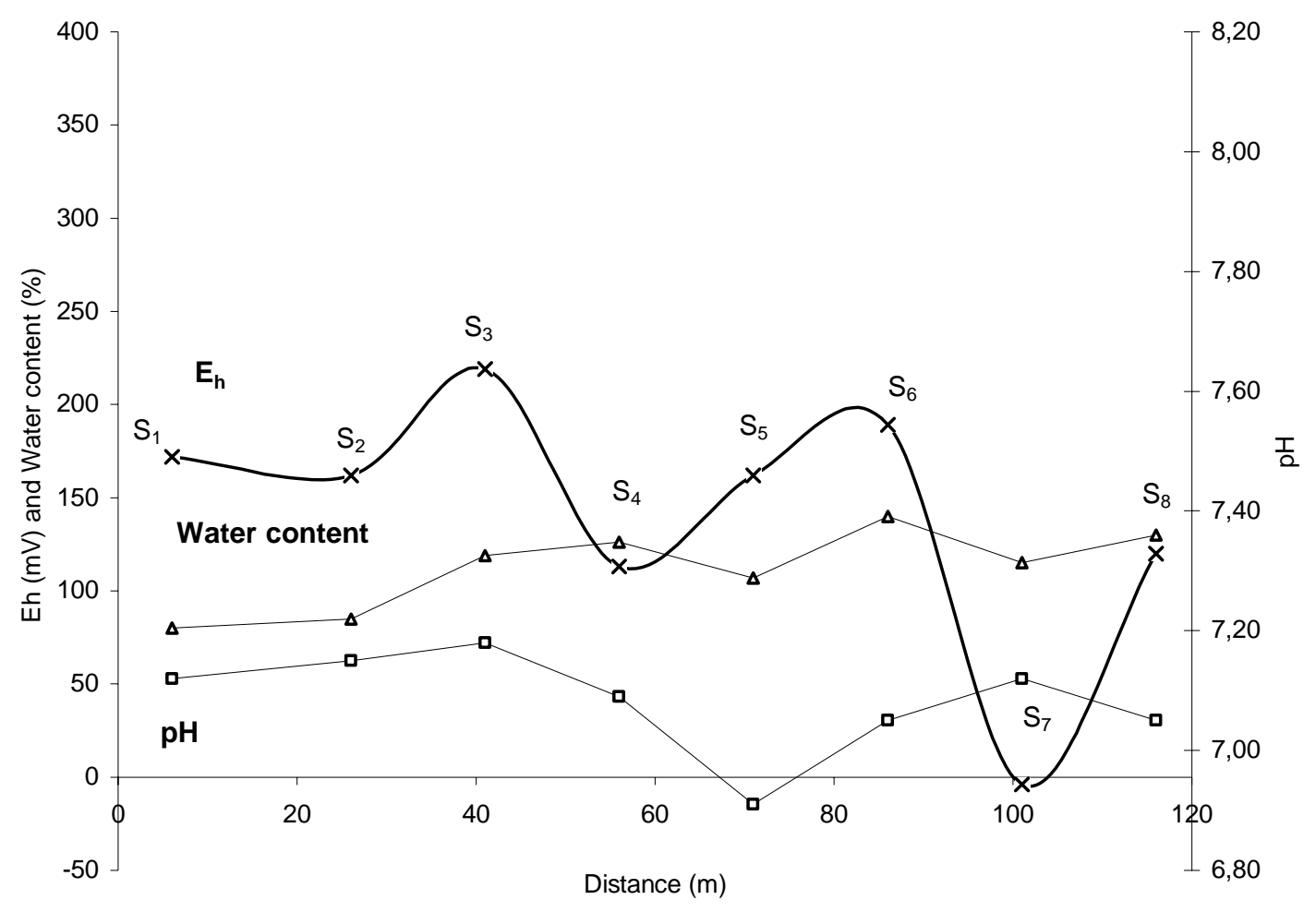

Box-and-whisker plots were used to represent the distribution of the chemical parameters of sediments and settling particles. In the fish pond, the sediments have higher concentrations and wider ranges in tot-P and tot-Fe than the settling particles (Fig. 6). No significant differences in tot- $\mathrm{P}(\mathrm{P}=0.6571)$ and tot-Fe $(\mathrm{P}=0.9784)$ were recorded between the OT and UT materials. The highest value of tot-P $\left(\cong 883 \mu \mathrm{g} \mathrm{P} \mathrm{g}{ }^{-1}\right)$ indicated by the extent whisker of the OT material was recorded in $\mathrm{OT}_{3}$ located behind the airlift. The material collected in $\mathrm{UT}_{1}$ was particularly rich in tot-Fe. The sediments have a wide range in TAN from 47 to $106 \mu \mathrm{g} \mathrm{N} \mathrm{g}$ in comparison with the settling particles. In the oyster pond, no significant difference was recorded between the OT and UT materials for TAN ( $P=0.7499)$. A maximum of $205 \mu \mathrm{g} \mathrm{P} \mathrm{g}^{-1}$ was recorded in $\mathrm{UT}_{5}$. The results showed no substantial variation between the sediments (SD) and settling particles (PA) for org- $\mathrm{C}$ and tot- $\mathrm{N}(P>0.500)$, whereas the average $\mathrm{C} / \mathrm{N}$ ratio (8.7 \pm 0.5 ) was higher in the sediments. The UT material was particularly rich in org- $\mathrm{C}$ and tot- $\mathrm{N}$ in comparison with the OT material, whereas the $\mathrm{C} / \mathrm{N}$ ratio ranging between 6.5 and 7.0 was 
similar in both materials (Fig. 6). The org- $\mathrm{C}$ and tot- $\mathrm{N}$ concentrations have as ranges 16.3$22.7 \mathrm{mg} \mathrm{C} \mathrm{g}^{-1}$ and 2.7-4.0 $\mathrm{mg} \mathrm{N} \mathrm{g}^{-1}$ respectively. 
Figure 6 Box-and-whisker plots of Tot-P (a), Tot-Fe (b), TAN (c), org-C (d), Tot-N (e) and C/N ratio (f) in the fish pond (sediments: SD and settling particles: PA) and oyster pond (materials trapped under the trestles: UT and out of the trestles: OT)
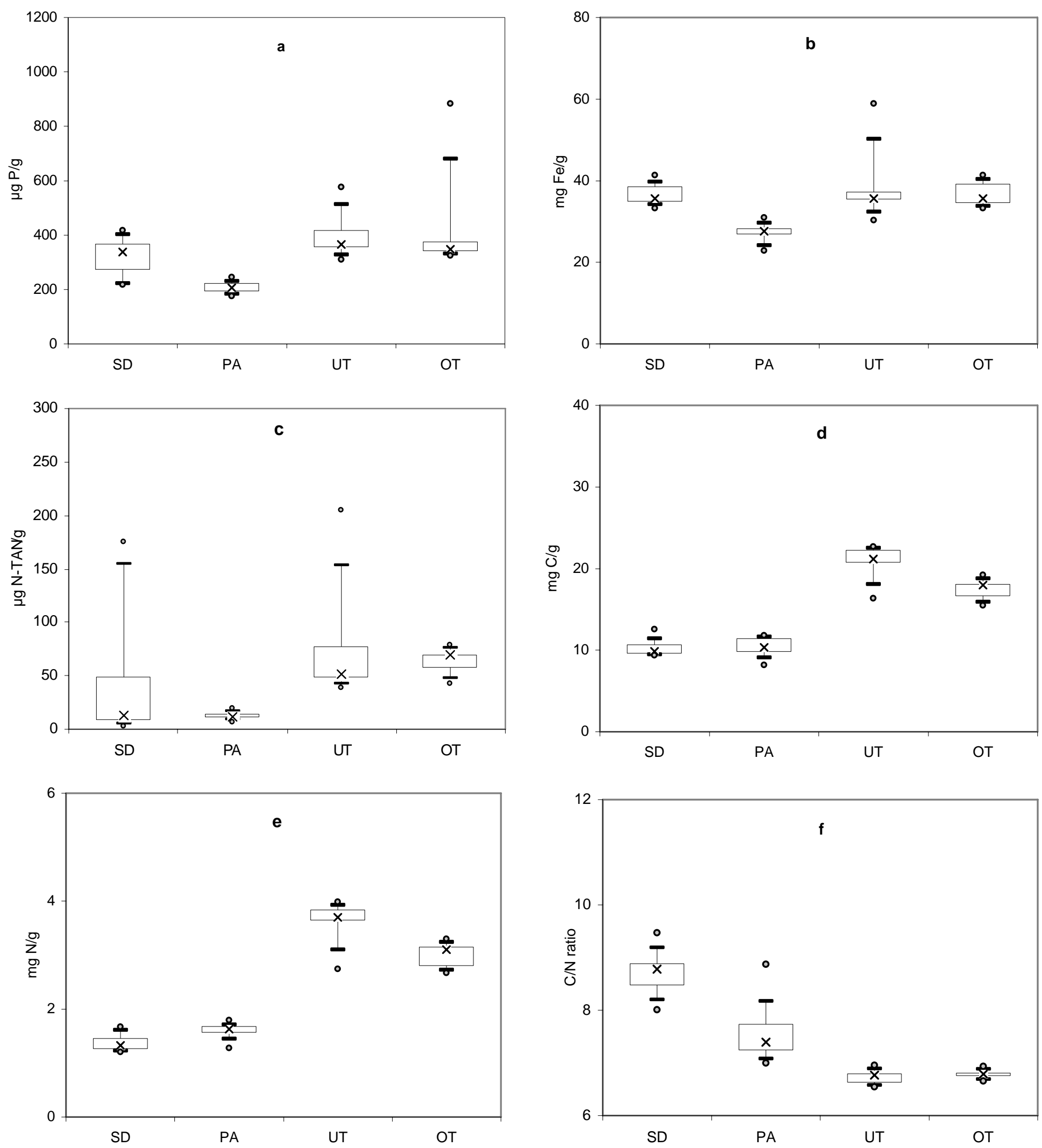
The results of P-fractionation and $\mathrm{Fe}(\mathrm{OOH})$ concentrations are presented in Fig. 7. The main differences between the sediments and settling particles are the high concentrations of $\mathrm{Fe}(\mathrm{OOH}) \approx \mathrm{P}$ and $\mathrm{CaCO}_{3} \approx \mathrm{P}$ in the fish pond sediments $\left({ }^{*} P<0.05\right)$. The settling particles have a small range for all $\mathrm{P}$-fractions except ROP. Inorganic $\mathrm{P}$ was the major fraction in the fish pond sediments with $64-77 \%$ of tot-P as range, whereas the $\mathrm{P}$ was primarily organic in the settling particles, with a range of $65-75 \%$ (Figure 8). In the oyster pond, the fractional composition of the UT material was not substantially different with that of the OT material $\left(\mathrm{P}=0.745,0.250,0.172,0.446\right.$ and 0.446 for $\mathrm{Fe}(\mathrm{OOH}) \approx \mathrm{P}, \mathrm{CaCO}_{3} \approx \mathrm{P}, \mathrm{ASOP}, \mathrm{NaOH}_{\mathrm{ext}}-\mathrm{P}$ and ROP respectively) (Fig. 7). The asymmetric distribution of $\mathrm{Fe}(\mathrm{OOH})-\mathrm{P}$ and $\mathrm{Fe}(\mathrm{OOH})$ in the OT material was due essentially to the highest values recorded in $\mathrm{OT}_{3}$ station $(\mathrm{Fe}(\mathrm{OOH}) \approx \mathrm{P}$ $=331 \mu \mathrm{g} \mathrm{P} \mathrm{g}^{-1}$ and $\left.\mathrm{Fe}(\mathrm{OOH})=7.95 \mathrm{mg} \mathrm{Fe} \mathrm{g}^{-1}\right)$. The distribution of the P-fractions was similar in both the UT and OT materials (Fig. 8). The $\mathrm{Fe}(\mathrm{OOH})-\mathrm{P}$ represented $32-37 \%$ of tot-P. 
Figure 7 Box-and-whisker plots of inorganic and organic $\mathrm{P}$ in the fish pond (sediments: SD and settling particles: PA) and oyster pond (materials trapped under the trestles: UT and out of the trestles: OT)
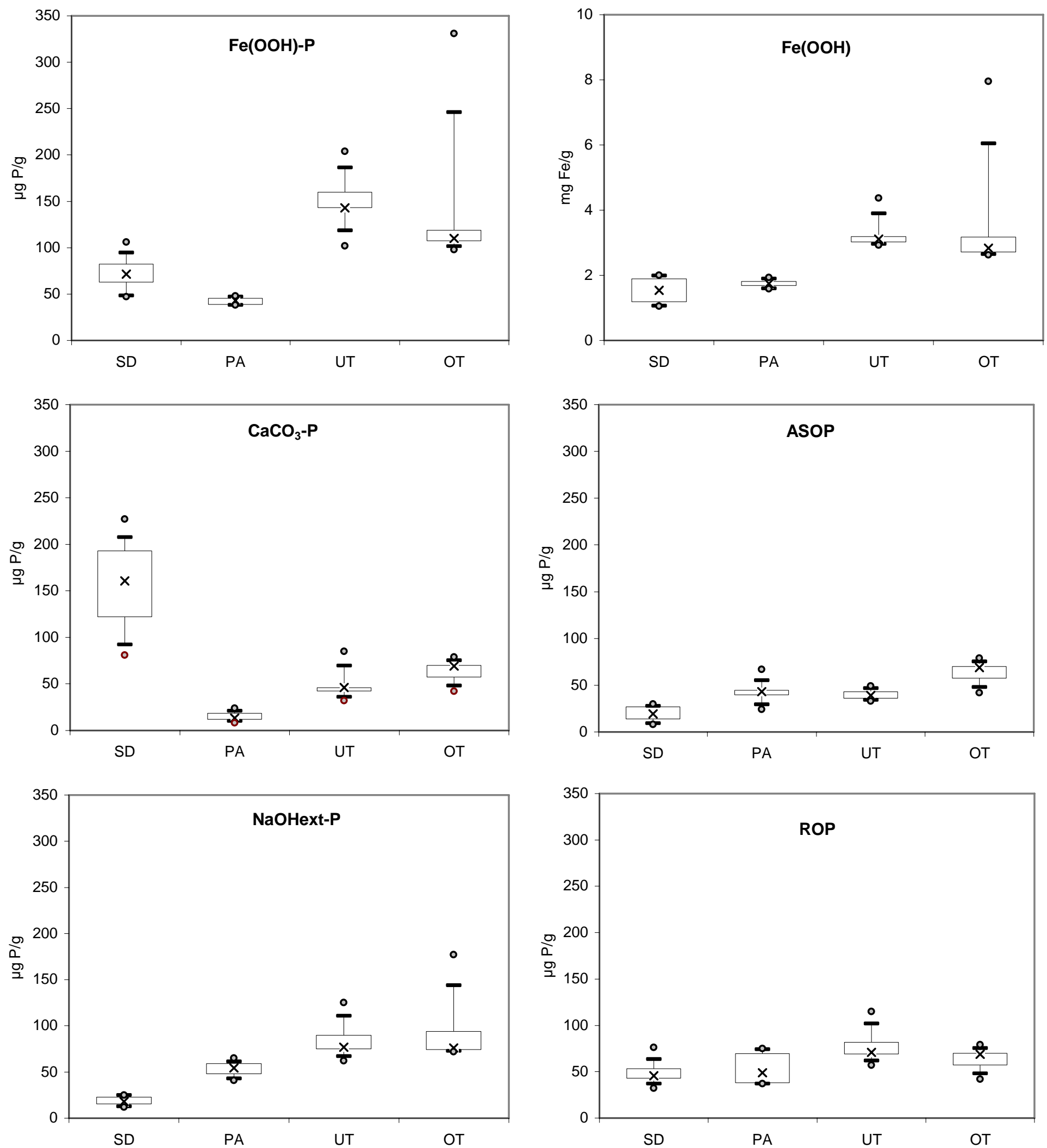
Figure 8 Proportions of the P-fractions in the sediments (SD), settling particles (PA), and materials collected under the trestles (UT) and out of the trestles (OT)

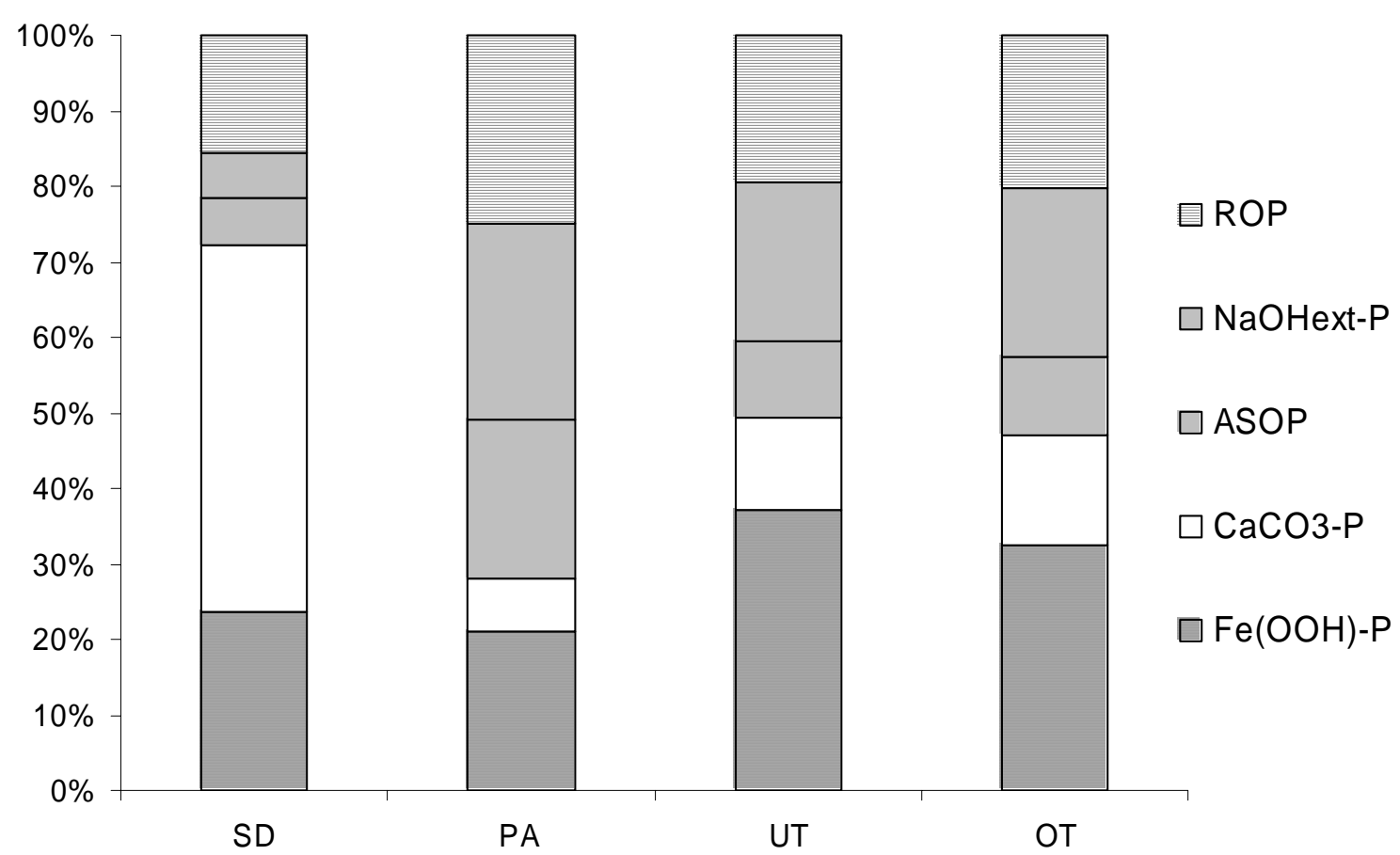

\section{Multivariate analysis}

To describe the inter-station variability, a principal components analysis (PCA) was performed taking all data of sediments and trapped particles. The first three axes explain $87 \%$ of the total variability (Fig. 9). The inset graph are related to the eigenvalues, which reflect the quality of the projection from the $\mathrm{N}$-dimensional initial table ( $\mathrm{N}=11$ Variables) to a lower number of dimensions. Each eigenvalue corresponds to a factor, and each factor to a one dimension. The first eigenvalue equals 6.217 and represents $56 \%$ of the total variability. The first two or three eigenvalues will correspond to a high \% of the variance, ensuring us that the maps based on the first two or three factors are a good quality projection of the initial multidimensional table. A partition into four groups was obtained through this analysis. The SD and PA stations were ranged into two distinct groups. The sediment stations are not separated clearly with axis 1 , whereas the axis 2 positively correlated with $\mathrm{CaCO}_{3} \approx \mathrm{P}$ and tot-Fe indicates the high variability of these sediments. The two first axis of the PCA analysis show low variability of the fish pond particles. Axis 1 gives the best discrimination between the oyster pond stations. The $\mathrm{UT}_{1}, \mathrm{OT}_{3}$ and $\mathrm{UT}_{5}$ stations appear to be distinct from the others. The first axis, which extracted $57 \%$ of the variance, selected positively TAN, org-C, tot-N and Pfractions, most important in the material trapped in the oyster pond. 
Figure 9 Principal Component Analysis using all data of the fish (sediments: SD and settling particles: PA) and oyster ponds (materials trapped under the trestles: UT and out of the trestles: OT)

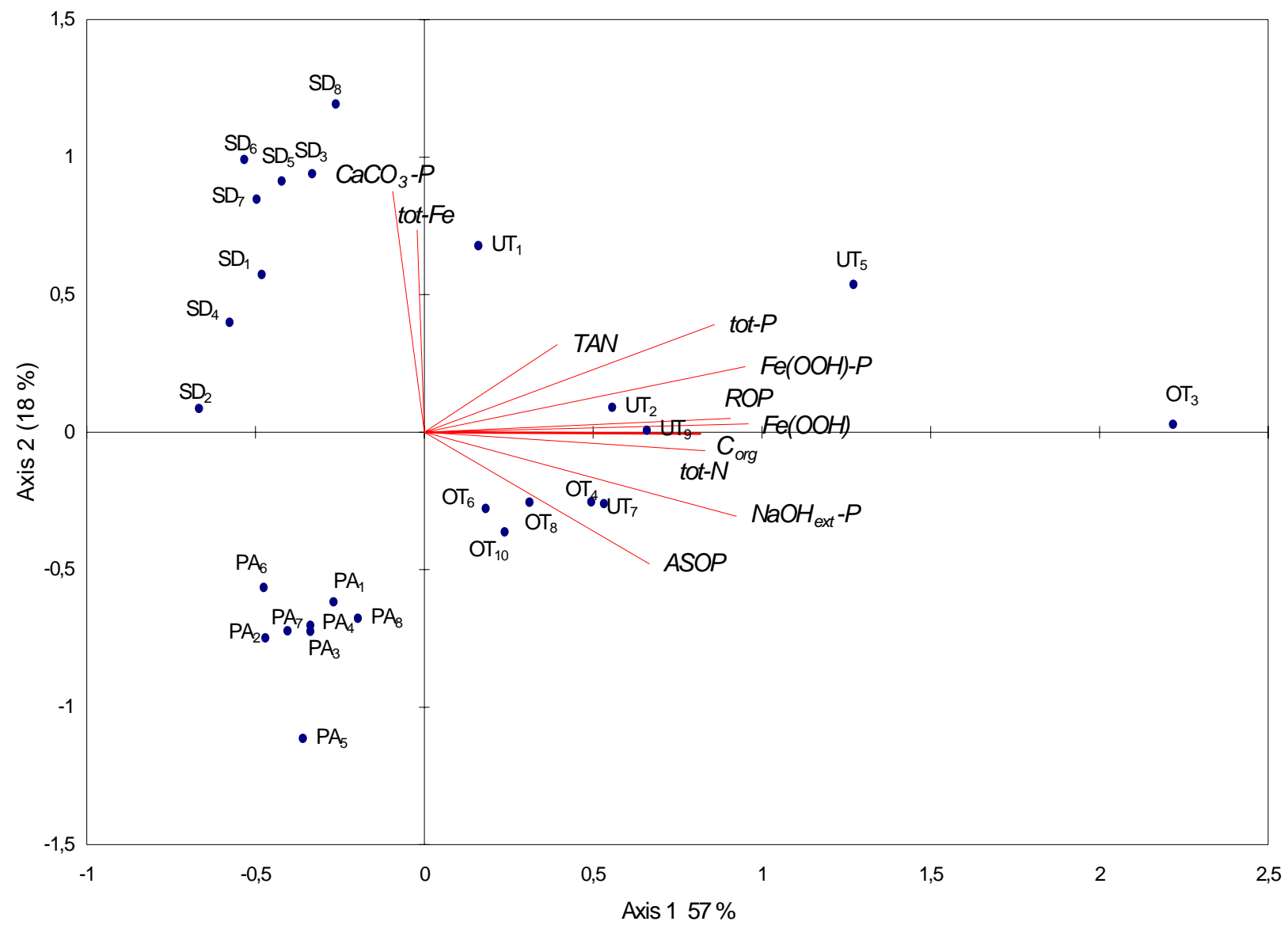

The results of the hierarchical ascending classification are summarized in Table 1 . In the fish pond, a partition into three classes was obtained for both the sediment and sediment trap stations. However, the oyster pond stations are mostly ranged in two classes (IV \& V). The $\mathrm{UT}_{1}, \mathrm{OT}_{3}$ and $\mathrm{UT}_{5}$ weakly correlated with the other groups are ranged in individual classes.

Table 1 Partition of the stations by hierarchical ascending classification

\begin{tabular}{|c|c|c|c|c|c|c|c|c|c|c|c|}
\hline \multirow[b]{3}{*}{ Class $n^{\circ}$} & \multicolumn{6}{|c|}{ Fish pond } & \multicolumn{5}{|c|}{ Oyster pond } \\
\hline & \multicolumn{3}{|c|}{ Sediment } & \multicolumn{3}{|c|}{ Sediment trap } & \multicolumn{5}{|c|}{ Sediment trap } \\
\hline & $\mathrm{I}$ & II & III & $\mathrm{I}$ & II & III & $\mathrm{I}$ & II & III & IV & V \\
\hline \multirow[t]{4}{*}{ Stations } & $\mathrm{SD}_{1}$ & $\mathrm{SD}_{2}$ & $\mathrm{SD}_{6}$ & $\mathrm{PA}_{1}$ & $\mathrm{PA}_{2}$ & $\mathrm{PA}_{6}$ & $\mathrm{UT}_{1}$ & $\mathrm{OT}_{3}$ & $\mathrm{UT}_{5}$ & $\mathrm{UT}_{2}$ & $\mathrm{OT}_{4}$ \\
\hline & $\mathrm{SD}_{3}$ & $\mathrm{SD}_{4}$ & $\mathrm{SD}_{7}$ & $\mathrm{PA}_{3}$ & $\mathrm{PA}_{5}$ & & & & & $\mathrm{UT}_{7}$ & $\mathrm{OT}_{6}$ \\
\hline & & $\mathrm{SD}_{5}$ & $\mathrm{SD}_{8}$ & $\mathrm{PA}_{4}$ & $\mathrm{PA}_{7}$ & & & & & $\mathrm{UT}_{9}$ & $\mathrm{OT}_{8}$ \\
\hline & & & & $\mathrm{PA}_{8}$ & & & & & & & $\mathrm{OT}_{10}$ \\
\hline
\end{tabular}




\section{Discussion}

The mean trapping rate of solids was $3975 \mathrm{~g} / \mathrm{m}^{2} / \mathrm{d}$ in the pond stocked with seabass at 13170 $\mathrm{kg} \mathrm{ha}^{-1}$. Trapping rates reported by Avnimelech et al. (1999) did not exceed $2042 \mathrm{~g} / \mathrm{m}^{2} / \mathrm{d}$ in tilapia pond stocked only with $5170 \mathrm{~kg} \mathrm{ha}^{-1}$. Aeration explains the high rates recorded at $\mathrm{S}_{3}$ and $S_{7}$. As the fish pond is muddy, the rapid flow rate created by the aerators leads to scouring and erosion of the pond banks, and to the accumulation of eroding particles in these stations. The high accumulation occurred at 30-40 m from the aerators. Fast \& Boyd (1992) reported that the organic residues from the sludge also accumulate in the near-stagnant region. Aerators can also act to resuspend bottom particles and drive substances across the watersediment interface. In Jimenez-Montealegre et al. (2002), the trapping rate was less than 380 $\mathrm{g} / \mathrm{m}^{2} / \mathrm{d}$ in a sandy pond stocked with tilapia at $2730 \mathrm{~kg} \mathrm{ha}^{-1}$. They have reported that the inorganic sediment was hardly resuspended, because the material was sandy, so the size and density of the particles was too large to be lifted higher than few centimeters into the water column.

In the oyster pond, the trapping rates of solids recorded in OT and UT stations are in agreement with the results reported by Sornin (1984). From the result obtained in $\mathrm{UT}_{1}$, the trapping rate of solids in UT stations seems to be proportional to the oyster biomass. Biodeposition constitutes the main factor that contributes to the accumulation of organic matter on the bottom. To avoid an important release of toxic factors such $\mathrm{H}_{2} \mathrm{~S}, \mathrm{FeS}$ and $\mathrm{NH}_{3}$ in the oyster pond, the bio-depot was removed each week from the pond bottom. A concrete pond was designed in to facilitate this operation.

Estimation of the magnitude of resuspension based on the dilution method indicated that resuspension was high relative to sedimentation from the water column. Sediment resuspension in most shallow water bodies is caused by shear from the oscillatory motion of wind-induced waves and from water currents (Hamilton \& Mitchell 1997). The results showed that the material from resuspension accumulated essentially in the stations where the water flow velocity decreased as in $\mathrm{S}_{3}$ and $\mathrm{S}_{7}$. Poorly consolidated sediment in shallow lakes and aquaculture ponds is very sensitive to resuspension (Lee, 1970). The resuspension rates are on average two times higher that the rates reported by Avnimelech et al. (1999). Breukelaar et al. (1994) reported a resuspension rate equaling about five times the fish biomass per $\mathrm{m}^{2}$ per day $\left(\cong 6640 \mathrm{~g} / \mathrm{m}^{2} / \mathrm{d}\right)$, which is higher than our values. Several studies have identified fish species, fish weight and/or fish bimass, to affect the resuspension rate in fish ponds (Avnimelech et al., 1999). Resuspension can be caused by bio-turbulence either by fish foraging at the pond bottom when artificial feeding was suspended, or by fish moving actively during feeding. As the aerators disturb continuously the pond bottom, it is not easy to evaluate the effect of fish on the resuspension rates.

Sediment and trapped material analysis

In the fish pond, the redox potential $\left(\mathrm{E}_{\mathrm{h}}\right)$ and water content varied strongly in the sediments except for $S_{1}$ and $S_{2}$ which are similar. The highest $E_{h}$ occurred particularly in sediments sampled at $\mathrm{S}_{3}$ and $\mathrm{S}_{6}$ located at 32 and $25 \mathrm{~m}$ respectively from the aerators. The results showed a direct action of the artificial aeration on the redox potential of sediments sampled in front of the aerators. Furthermore, the artificial aeration has no effect on $E_{h}$ in the sediments sampled at a distance up to $40 \mathrm{~m}$ from the aerators. Indeed, a significant decrease of $\mathrm{E}_{\mathrm{h}}$ occurred in sediments of $\mathrm{S}_{4}$ and $\mathrm{S}_{7}$. When oxygen is depleted, other terminal electron acceptors can be used to mediate the decomposition of organic matter (Avnimelech \& Ritvo, 2003). Since Eh ranged between - 4 and $+220 \mathrm{mV}$, nitrate, iron and manganese serve subsequently as electron acceptors when oxygen is depleted (Reddy et al., 1996). 
Box-and-whisker plots were used as graphical/statistical tool to visualize the descriptive statistical characteristics of data from the sediments and settling particles. In the fish pond, the sediments have high concentrations of tot-P, tot-Fe and TAN in comparison with the settling particles. The feed input (1.5\% P) constitutes the major source of $\mathrm{P}$ in the fish pond. Masuda \& Boyd (1994) found about $67 \%$ of phosphorus applied to ponds in feed accumulates in bottom soils. Lin \& Nash (1996) estimated that 26\% of the phosphorus applied as feed accumulated in the shrimp pond sediments. As tot-P was under $400 \mu \mathrm{g} \mathrm{g}^{-1}$ in the sediments, the pond has received little amount of $\mathrm{P}$ as feed. The results reported in the previous study indicated that Tot-P exceeded $3400 \mu \mathrm{g} \mathrm{P} \mathrm{g}^{-1}$ in the highly fertilized ponds (Kassila, 2003). The sediments have a wider range of TAN than the settling particles. The concentrations in these particles were less than $20 \mu \mathrm{g} \mathrm{N} \mathrm{g}$. Most of the release of adsorbed ammonium from resuspended sediment occurred within 15 min (Reddy et al. 1996). The standard classification of sediments for pond aquaculture leads to consider the fish pond sediments as mineral with high organic matter content (Boyd et al., 2002). In mineral sediments, organic matter is considered to be labile if micro-organisms can decompose it readily. The high $\mathrm{C} / \mathrm{N}$ ratios indicate that the organic matter in the fish pond sediments was more highly degraded in comparison with that in the settling particles.

The tot-P concentrations in UT material were lower in comparison with the concentrations reported in previous studies on bio-settling particles (Sornin et al., 1986; Edwards \& Welsh, 1982; Geesey et al., 1984). This observation suggests that the UT material did not originate only from the oyster faeces and pseudo-faeces but also from other sources poorly in $\mathrm{P}$. However, the UT material was characterized by the high concentrations of KCl-extractable TAN. The concentrations were comparable with those in other aquaculture systems with high $\mathrm{N}$ loads. Of the $\mathrm{N}$ adsorbed by oysters, approximately $10 \%$ goes to growth, $10 \%$ to gametes, $2 \%$ to byssal threads, with $50 \%$ lost as bio-deposition and $27 \%$ as excretion (Dame, 1996). The mean trapping rate of solids was three times higher under the oyster trestles. The material consisting mostly of oyster rejection products was less degraded (lower $\mathrm{C} / \mathrm{N}$ ratio). The similarity in the $\mathrm{C} / \mathrm{N}$ ratios indicated that the organic matter of UT material was not different with that of OT material.

The iron- and calcium-bound $\mathrm{P}$ represented 23 and $47 \%$ of tot-P respectively in the fish pond sediments. Under anoxic conditions, $\mathrm{Fe}(\mathrm{OOH}) \approx \mathrm{P}$ can be easily released after the reduction of $\mathrm{Fe}(\mathrm{OOH})$ according to the results of Matejka et al. (1992). During an earlier study, we demonstrated that about $75 \%$ of the tot-P released in anoxic conditions came from $\mathrm{Fe}(\mathrm{OOH}) \approx \mathrm{P}$ (Kassila et al., 2001). The tot-P was essentially in organic form in the settling particles. The uneaten feed and fish faeces constitute probably the major source of org-P for these particles. The homogeneity in chemical composition of the settling particles leads to consider the feeding activity of fish uniform on the pond area. Additionally, the aeration contributes to homogenize the water composition in resuspended particles.

In the oyster pond the fractional composition was similar in both the UT and OT materials. As, $\mathrm{P}$ and Fe were added in the phytoplankton ponds to promote their development, high concentrations of $\mathrm{Fe}(\mathrm{OOH}) \approx \mathrm{P}$ from the oyster feaces were retrieved in the trapped material. 


\section{Mass balance}

The uneaten feed is considered to be about of $10 \%$ of the feed load (Kishi et al., 1994). Lemarié et al., 1998 have estimated the uneaten feed to be $175 \mathrm{~g}$ per $\mathrm{kg}$ of crude pellet and the fecal output about of $154 \mathrm{~g}$ per $\mathrm{kg}$ of the food delivered. According to these results, $15 \mathrm{~kg}$ as a daily feed input in the CREEA ponds produced an uneaten feed flux of $4.37 \mathrm{~g} / \mathrm{m}^{2} / \mathrm{d}$ and 3.85 $\mathrm{g} / \mathrm{m}^{2} / \mathrm{d}$ as a fecal flux. The expected feed and fecal output estimated by the sum of these fluxes $\left(8.22 \mathrm{~g} / \mathrm{m}^{2} / \mathrm{d}\right)$ constitutes only $0.6-1.4 \%$ of the sedimentation rates presented in fig 3-a. As the chl a concentration did not exceed $2 \mu \mathrm{g} / \mathrm{l}$ in the fish pond, the primary production did not represent a large part of TSS. The aerators positioned in front of the bottom resuspended the sediment particles and limit therefore the algal growth. This means that the dilution method overestimated the sedimentation rates and did not give reliable results in the highly aerated ponds to partition the sources of trapped particulate matter. The effect of aerators must be included in this method to improve their efficiency.

The nitrogenous content in fish feces was estimated to be around of $5.1 \% \mathrm{~N}$ with similar feed product (Lemarié et al., 1998). The Tot-N fluxes were then estimated to be 0.35 and $0.19 \mathrm{~g}$ $\mathrm{N} / \mathrm{m}^{2} / \mathrm{d}$ in the feed and the fecal output fluxes respectively. The sum of these fluxes represents only $25-68 \%$ of the fluxes estimated by the dilution method (Fig.4).

The oysters removed large concentration of phytoplankton, bacteria en other suspended solids from the water column, and produced feaces and pseudofeaces at a rates of 9-26 mg (g dry $\mathrm{wt})^{-1}$. These rates are under the ranges of $66-246 \mathrm{mg}(\mathrm{g} \text { dry } \mathrm{wt})^{-1}$ observed for the pacific oyster, Crassostrea gigas (Boucher \& Boucher-Rodoni, 1988). This result indicates the efficiency of the sedimentation pond to reduce the concentration of suspended particles prior to filtration by oysters.

\section{Multivariate analysis}

The PCA analysis leads to consider the $\mathrm{CaCO}_{3} \approx \mathrm{P}$ and tot-Fe as the key factors to describe the spatial heterogeneity of the fish pond sediments. These variables will be sufficient to define a novel sampling strategy for sediments. Sampling should be designed to estimate a few selected variables with a certain degree of accuracy at the lowest possible cost (Petersen and Calvin, 1986). However, this analysis gives no indication on the heterogeneity of settling particles in the fish pond. The artificial aeration tended to homogenize the water content in particles from resuspension and bank erosion.

In the oyster pond, the OT stations are highly inter-correlated except for $\mathrm{OT}_{3}$. As a result, one or two stations can be selected to study the chemical variability of the OT material during the rearing period. This result indicates that the airlifts assume a best mixing of the water column in suspended particles. As $\mathrm{OT}_{3}$ was located in a stagnant area behind the airlift 2, the material trapped was different from the other OT materials. The UT stations were largely scattered in comparison with the OT stations. $\mathrm{UT}_{1}$ was correlated positively with the axis 1 . The sediment trap placed at $\mathrm{UT}_{1}$ collected some particles from the eroded bank. An abundant element in soil as Fe founded at high concentrations in $\mathrm{UT}_{1}$ material confirms this assumption.

A partition of the studied stations into different classes was performed by the hierarchical ascending classification. To assess the seasonal variations of the sediments and settling particles, one station could be selected from each group during the next sampling. The purpose of the sampling is to estimate different parameters with an accuracy which will meet our needs at the lowest possible cost. However, a difficulty that occurs in assessing the efficiency of estimators in the spatial setting is the tendency of sample readings to be positively-spatially correlated over the field (Warrick et al., 1986). In other words, two measurements taken at locations separated by short distances tend to have higher similarity 
than two measurements taken at locations separated by a greater distance. This correlation needs to be accounted during the selection of stations from the classes. For this reason, we avoided to choose for example $\mathrm{SD}_{3}$ and $\mathrm{SD}_{4}$ from classes I and II respectively as a short distance separate these stations. The $\mathrm{SD}_{3}, \mathrm{SD}_{5}$ and $\mathrm{SD}_{7}$ stations were, therefore, selected for the next sampling to estimate the chemical parameters of the sediments with high accuracy. For sediment traps, the choice of the stations must be done also with respect to the biodeposition rates. The $\mathrm{PA}_{3}, \mathrm{PA}_{5}$ and $\mathrm{PA}_{6}$ stations were selected as they gave a mean biodeposition rate not substantially different with that estimated from the eight stations.

Most studies used generally one parameter to propose a sampling procedure to remove the sediment (Brune and Eversole, 1993; Ritvo et al., 1998). The utilization of several parameters in the present study leads to the development of a strategy more efficient than the above studies.

\section{Acknowledgements}

We acknowledge the financial help of Conseil régional de Poitou-Charentes, Ifremer and the European Community (Genesis Innovation Project). We would also like to thank Lucette Joassard and the CREEA Staff for technical assistance.

\section{References}

Avnimelech Y., Kochva M. \& Hargreaves J.A. (1999) Sedimentation and resuspension in earthen fish ponds. Journal of World Aquaculture Society 30, 401-409.

Avnimelech Y. \& Ritvo G. (2003) Shrimp and fish pond soils: processes and management. Aquaculture 220, 549-567.

Banas D., Capizzi S., Masson G., Leglize L., Wagner P. \& Pihan J.C. (2002) New sediment traps for drainable shallow freshwater systems. Revue des Sciences de l'Eau 15/1, 263272.

Banas D. \& Masson, G. (2003) New plate sediment traps for lentic systems. Archives of Hydrobiology 158, 283-288.

Boucher G. \& Boucher-Rodoni, R. (1988) In situ measurement of respiratory metabolism and nitrogen fluxes at the interface of oyster beds. Marine Ecology Progress Series 44, 229238.

Boyd C.E. (1995) Bottom soils, sediment, and pond aquaculture. Chapman and Hall, New York, 348 pp.

Boyd C.E. (1998) Pond water aeration systems. Aquaculture Engineering 18, 9-40.

Boyd C.E., Wood C.W. \& Thunjai T. (2002) Pond soil characteristics and dynamics of soil organic matter and nutrients. In: McElwee K., Lewis K., Nidiffer M. \& Buitrago P. (Eds.), Nineteenth Annual Technical Report. Pond Dynamics/Aquaculture CRSP, Oregon State University, Corvallis, Oregon, 1-10.

Breukelaar A.W., Lammens E.H.R.R., Breteler J.G.P.K. \& Tatrai I. (1994) Effects of benthivorous bream (Abramis Brama) and carp (Cyprinus carpio) on sediment resuspension and concentrations of nutrients and chlorophyll-a. Freshwater Biology 32, 113-121.

Brune D.E. \& Eversole A.G. (1993) Pond nutrient dynamics in crawfish culture ponds. In: Techniques for Modern Aquaculture, American Society of Agriculture Engineers. St. Joseph, MI., 533-542. 
Butz I. \& Vens-Cappell B. (1982) Organic load from the metabolic products of rainbow trout fed with dry food. In Albaster, J.S. (Ed.), Report on the EIFAC Workshop on Fish Farm Effluents. Silkeborg, Denmark, 26-28 May 1981, EIFAC Tech. Pap. 41, 57-70.

Dame R.F. (1996) Ecology of Marine Bivalves: An Ecosystem Approach. CRC Press, New York.

De Groot C.J. (1990) Some remarks on the presence of organic phosphate in the sediment. In Bonin D.J. \& Golterman H. L. (Eds.), Fluxes Between Trophic Levels and Trough the Water-Sediment Interface. Developments in Hydrobiology 62. Kluwer Academic Publishers, Dordrecht, 303-311. Reprinted from Hydrobiologia 207.

Edwards S.F. \& Welsh B. (1982) Trophic dynamics of mud snail (Ilyanassa obsoleta, Say) population on an intertidal mudflat. Estuarine Coastal and Shelf Science 14, 663-686.

Fast A.W. \& Boyd C.E. (1992) Water circulation, aeration and other management practices. In: Fawt A.W. \& Lester L.J. (Eds.) Marine Shrimp Culture: Principles and Practices. Elsevier Science Publishers, The Hague, Netherlands, 457-495.

Gardner W.D. (1980) Sediment traps dynamics and calibration: a laboratory evaluation. Journal of Marine Research 38, 17-39.

Geesey G., Alexander G.V., Bray R.N., Miller A.C. (1984) Fish feed pellets are a source of minerals for inshore reef communities. Marine Ecology Progress Series 15, 19-25.

Golterman H.L. (1996) Fractionation of sediment phosphate with chelating compounds: a simplification, and comparison with other methods. In Golterman, H.L., (Ed.), SedimentWater Interaction 6. Hydrobiologia 335, 87-95.

Golterman H.L., Clymo R.S., Ohnstad M.A.M. (1978) Methods for physical and chemical analysis of freshwaters, IBP Manual $\mathrm{N}^{\circ} 8\left(2^{\text {nd }}\right.$ Ed.). Blackwell Scientific Publications, Oxford, 213 pp.

Hamilton D.P. \& Mitchell S.F. (1997) Wave-induced shear stress, plant nutrients and chlorophyll in seven shallow lakes. Freshwater Biology 38, 159-168.

Hopkins J.S., Sandifer P.A., Browdy C.L. (1995) A review of water management regimes which abate the environmental impacts of shrimp farming. In: Browdy, C.L., Hopkins, J.S. Eds. , Swimming ThroughTroubled Water, Proceedings of the Special Session on Shrimp Farming, Aquaculture '95. World Aquaculture Society, Baton Rouge, LA, USA, pp. 157-166.

Hussenot J.M.E. (2003) Emerging effluent management strategies in marine fish-culture farms located in European coastal wetlands. Aquaculture 226, 113-128.

Hussenot J.M.E. \& Shpigel M. (2003) Marine land-based integrated aquaculture systems for European countries and the European Innovation Project "GENESIS". European Aquaculture Society 33, 31-36.

Jimenez-Montealegre R., Verdegem M., Zamora J.E. \& Verreth J. (2002) Organic matter sedimentation and resuspension in tilapia (Oreochromis niloticus) ponds during a production cycle. Aquacultural Engineering 26, 1-12.

Jones A.B. \& Preston N.P. (1999) Oyster filtration of shrimp farm effluent, the effects on water quality. Aquaculture Research 30, 51-57.

Jorgensen B.B. (1996) Material flux in the sediment. In : Jorgensen, B.B., Richardson, K. (Eds.) Eutrophication in coastal marine ecosystems. Coastal and estuarine studies 52. American Geophysical Union, Washington, 115-135. 
Kassila J., Hasnaoui M. \& Yahyaoui, A. (2000) Sequential extractions of inorganic and organic Phosphate from fish pond sediments (Deroua station, Beni Mellal, Morocco) by different fractionation methods. Hydrobiologia 431, 51-58.

Kassila J., Hasnaoui M., Droussi M., Loudiki M. \& Yahyaoui A. (2001) Relation between phosphate and organic matter in pond sediments of the Deroua fisheries farm (BéniMellal, Morocco): Implications for pond management. Hydrobiologia 450, 57-70.

Kassila J. (2003) Effects of lining and drying on the chemical composition of sediments and influence of organic carbon on carp growth in aquaculture ponds. Aquaculture Research 34, 333-343.

Kishi M., Uchiyama M \& Iwata Y. (1994) Numerical simulation model for quantitative management of aquaculture. Ecological Modeling 72, 21-40.

Koroleff J. \& Grasshoff, K. (1983) Determination of nutrients. In: Grasshoff, K., Ehrahardt, M., Kremling, K.. Methods in seawater analysis. Weiheim, Deerfield Beach, Florida, Basel 125-188.

Kozerski H.P. \& Leuschner K. (1999) Plate sediment traps for slowly moving waters. Water Research 33/13, $2913-2922$.

Lee G.F. (1970) Factors affecting the transfer of materials between water and sediments. Eutrophication Information Program Literature Review 1. University of Wisconsin, Madison, Wisconsin, USA.

Lefebvre S. (2000) Les cycles de l'azote et du phosphore dans un système aquacole intégré poisson-phytoplancton-bivalve: études expérimentales et modélisations. Thèse de doctorat en biologie marine, Université de Nantes. 224 pp.

Lefebvre S., Bacher C., Meuret A., Hussenot J. (2001) Modelling approach of nitrogen and phosphorus exchanges at the sediment-water interface of an intensive fish pond system. Aquaculture 195, 2791-297.

Lemarié G., Martin J.L.M., Dutto G. \& Garidou C. (1998) Nitrogenous and phosphorus waste production in a flow-through land-based farm of European seabass (Dicentrarchus labrax). Aquatic Living Resources 11 (4), 247-254.

Lin C.K. \& Nash.G.L. (1996) Asian Shrimp News, Collected Columns, 1989-1995. Asian Shrimp Culture Council, Bangkok, Thailand.

Martin J.L.M., Veran Y., Guerlorget O., Pham D. (1998) Shrimp rearing: stocking density, growth, impact on sediment waste output and their relationships studied through the nitrogen budget in rearing ponds. Aquaculture 164, 135-149.

Masuda K. \& Boyd C.E. (1994) Phosphorus fractions in soil and water of aquaculture ponds built on clayey Ultisols at Auburn, Alabama. Journal of World Aquaculture Society 25, 379-395.

Matejka G., Feuillade G., Heulot I., Lemehaute P.\& Mazet M. (1992) Les échanges de phosphore à l'interface eau-sédiments- Etudes et mémoires. Tribune de l'eau, Mars/Avril, 556/2, 19-25.

Mesnage V. \& Picot B. (1993) Comparison of two methods for the fractionation of the sediment bound phosphate: Estimation of phosphate fractions mobility. Journal Français d'Hydrologie 24, 55-68.

Murphy J. \& Riley J.P. (1962) A modified single solution method for the determination of phosphate in natural waters. Analytica Chimica Acta 27, 31-36. 
Peterson R.G. \& Calvin L.D. (1986) Sampling. In: Kulte, A. (Ed.), Methods of Soil Analysis. Part 1. Physical and Mineralogical Methods. Agronomy 9, $2^{\text {nd }}$ ed., Part 1, 33-51.

Reddy K.R., Fisher M.M. \& Ivanoff D. (1996) Resuspension and diffusive flux of nitrogen and phosphorus in a hypereutrophic lake. Journal of Environmental Quality 25, 363-371.

Rosa F., Bloesh J. \& Rathke D.E. (1994) Sampling the settling and suspended particulate matter. In: Mudroch, A., MacKnight, S.D. (Eds.), Techniques for aquatic sediments sampling, Lewis Publishers, Boca Raton, 97-130.

Ritvo G., Sherman M., Lawrence A.L. \& Samocha T.M. (1998) Determining the bottom soil sampling rate in shrimp ponds using variograms. Aquacultural Engineering 17, 273-282.

Shpigel M, Neori A., Popper D.M \& Gordin H. (1993) A proposed model for "environmentally clean" land-based culture of fish, bivalves and seaweeds. Aquaculture 117, 115-128.

Sornin J.M. (1984) Rôle et conséquences de la biodéposition à l'interface eau-sédiment. Journal de la Recherche Océanographique 9, 38-40.

Sornin J.M. Feuillet M., Héral M., Fardeau J.C. (1986) Influence des cultures d'huîtres Crassostrea Gigas sur le cycle du phosphore en zone intertidale: rôle de la biodéposition. Oceanologica Acta 9 (3), 313-322.

Sornin J.M., Collos Y., Delmas D., Feuillet-Girard M. \& Gouleau, D. (1990) Nitrogenous nutrient transfers in oyster ponds: role of sediment in deferred primary production. Marine Ecology Progress Series 68, 15-22.

Warrick A.W., Myers D.E. \& Nilsen D.R. (1986) Geostatistical methods applied to soil science. In: Kulte, A. (Ed.) Methods of Soil Analysis. Part 1. Physical and Mineralogical Methods. Agronomy 9, $2^{\text {nd }}$ ed., 53-82.

\section{List of abbreviations}

\begin{tabular}{|c|c|}
\hline ASOP & $=$ Acid soluble Org-Phosphate \\
\hline $\mathrm{CaCO}_{3} \approx \mathrm{P}$ & $=$ Calcium bound phosphate \\
\hline $\mathrm{Fe}(\mathrm{OOH}) \approx \mathrm{P}$ & $=$ Iron bound phosphate \\
\hline $\mathrm{NaOH}_{\mathrm{ext}}-\mathrm{P}$ & $=$ Org-Phosphate extracted by $\mathrm{NaOH}$ \\
\hline o-P & $=$ Soluble ortho-phosphate \\
\hline ROP & $=$ Residual organic phosphate \\
\hline Tot-P & $=$ Total phosphate \\
\hline Tot-Fe & $=$ Total iron \\
\hline Tot-N & $=$ Total nitrogen \\
\hline TAN & $=$ Total ammonium nitrogen $\left(\mathrm{NH}_{3}+\mathrm{NH}_{4}{ }^{+}\right.$ \\
\hline
\end{tabular}

